\title{
Donald Nixon Ross FRCS, FRCP (4 October 1922-7 July 2014)- and we called him Mr. Ross
}

\author{
Yutaka Okita
}

Published online: 18 September 2014

(C) The Japanese Association for Thoracic Surgery 2014

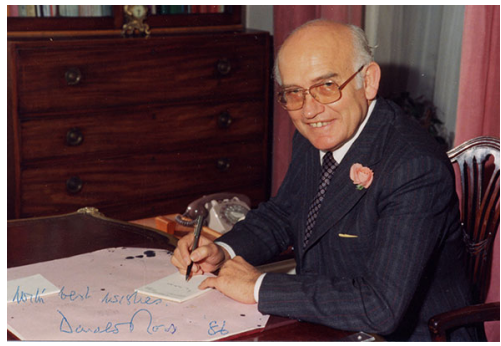

Donald Nixon Ross died on 7 July 2014 in London at the age of 91 . He was born of Scottish parents in Kimberley, South Africa, on 4 October 1922. He began his medical career enrolling as a student at the University of Cape Town. He graduated (B.Sc., MB, ChB) in 1946 with firstclass honors and the university gold medal. He had been a fellow student of Chirstiaan Barnard at the University of Cape Town, the man who carried out the world's first heart transplantation at Cape Town's Groote Schuur Hospital on 3 December 1967. Mr. Ross had also received a two-year overseas scholarship, which allowed him to further his studies in the United Kingdom.

He started to work initially in Bristol and he focused on chest and esophageal surgery. He became a Fellow of the Royal College of Surgeons (1949) within 2 years instead of the usual three. He was appointed as the Senior Registrar in Thoracic Surgery, Bristol, in 1952. Mr. Ross has recorded how Ronald Belsey, MD, the esophageal surgeon in Bristol with whom he was working, took him to Guy's Hospital on

Y. Okita $(\bowtie)$

Division of Cardiovascular Surgery, Kobe University, 7-5-2

Kusunoki-cho, Chuo-ku, Kobe, Japan 650-0017

e-mail: yokita@med.kobe-u.ac.jp
London to see Lord Russell Brock FRCS, FRCP attempt to split open a calcified aortic valve. Lord Brock, in charge of surgery at Guy's Hospital, took on Mr. Ross as a cardiovascular Research Fellow (1953) and later as Senior Thoracic Registrar (1954). Mr. Ross developed the Guy's-Ross hypothermic cardiopulmonary bypass machine. Four years later, in 1958, Mr. Ross was appointed as Consultant Cardiothoracic Surgeon at The Guys, and subsequently Consultant Surgeon, National Heart Hospital in London (1963), and Senior Surgeon there (1967). In 1970, he was made Director of the Department of Surgery at the Institute of Cardiology, London. He also practiced in the Harley Street Clinic in London. Mr. Ross retired in 1997.

It was in 1968 that Donald Ross led the team of doctors and nurses at the National Heart Hospital in London in the United Kingdom's first heart transplantation. It was the 10th of its kind-the first had been performed in South Africa by Chirstiaan Barnard the previous year. The operation, on a 45-year-old man, lasted $7 \mathrm{~h}$. The patient survived for another 46 days before dying from infection. Emerging to meet the press when it was over, Mr. Ross had to fend off rumors that the donor had been "murdered". Only six more heart transplants were carried out in Britain before a moratorium was declared.

In 1962, Mr. Ross introduced the use of allografts to replace diseased aortic valves. He used a technique of subcoronary implantation developed in the laboratory by Carlos Duran and Alfred Gunning at Oxford. Simultaneously but independently, Sir Brian Gerald Barratt-Boyes developed a similar technique in the Green Lane Hospital in Auckland, New Zealand. Mr. Ross championed the physiologic advantages of such grafts and simplified their surgical implantation technique. Another great achievement of his was the development, in 1967, of what has been termed the Ross procedure, or pulmonary autograft for 
aortic valve disease. Despite early promise, allografts had a limited life span of around 8 years. The pulmonary autograft was the logical development of the homograft. The benefits of the procedure were that it did not require lifelong anticoagulation with its attendant risks, and it could grow proportionately with the patient, making it suitable for use in children. Mr. Ross also developed the technique of implanting a pulmonary autograft in the mitral position, known as Ross II procedure.

Mr. Ross travelled widely, introducing open-heart surgery to India, Egypt, and Thailand. Many international colleges and surgical societies honored him. He became an honorary member of the Japanese Association for Thoracic Surgery (JATS) in 1998, given by the 51st president of JATS Dr. Hitoshi Koyanagi. Before that, he was invited by JATS in 1972 by the 25th president Dr. Saburo Sugie, and in 1988 by the 41 st president Dr. Tatsuta Arai. He gave us unforgettable lectures and demonstrated a fantastic world of the autograft and allograft valve implantation.
He educated many young cardiac surgeons, domestic or internationally. As for Japanese surgical society, Drs. Shigehito Miki (Kyoto), Tsuyoshi Fujita (Osaka), Torao Takahashi (Nagoya), Yuichi Ueda (Tenri), Yutaka Okita (Tenri), Takafumi Tahata (Tenri), Osamu Matsuki (Osaka) et al. were trained by him. I really enjoyed not only his orchestrations and techniques in the theatre but also the "evening drink" with pouring English-Scottish-South African humor with his beautiful and talented secretaries in the 25 Upper Wimpole Street office. His reputation was such that former students and admirers in the profession established a Donald Ross Surgical Society.

$\mathrm{He}$ is survived by his second wife, Barbara, a head nurse at the Harley Street Clinic, and by Janet, a dermatologist, a daughter of his first marriage to Dorothy, a scrub nurse in Bristol.

We all thank him for making cardiac surgery a more exciting field and a healing resort for the patients. 